\title{
KATYŃ. REAKTYWACJA
}

ALEXANDER ETKIND,

RORY FINNIN, UILLEAM BLACKER,

JULIE FEDOR, SIMON LEWIS,

MARIA MÄLKSOO, MATILDA MROZ,

REMEMBERING KATYN

Joanna Wawrzyniak

Uniwersytet Warszawski

Historyk Robert Traba pisal niedawno o nowym polskim rozdaniu w badaniach nad pamięcią zbiorową (Traba 2011: 8). Wydaje się, że o nowym rozdaniu, czy też o nowej fali badań, można mówić także w szerszym planie Europy Wschodniej. Recenzowana książka należy do kilku ważnych na rynku międzynarodowym publikacji, które ukazały się w latach 2010-2013, pokazując możliwości ujęć porównawczych i transnarodowych w regionie. Kontekst tych badań ma nieco dłuższą historię: po przyłączeniu nowych państw członkowskich do Unii Europejskiej, w ramach rozważań dotyczących „europeizacji” różnych dziedzin życia społecznego, rozpoczęły się również dyskusje na temat stanu europeizacji pamięci zbiorowej w społeczeństwach postkomunistycznych. Kwestie definicyjne dotyczące „europeizacji” i „pamięci zbiorowej” zostawmy na boku: obu terminów używa się w zbyt wielu znaczeniach i zbyt wielu mają krytyków. Ważne, że dyskutanci przedstawiali argumenty normatywne i opisowe, skupiając się przede wszystkim na stosunku społeczeństw Europy Wschodniej do Zagłady i stosując miary z atlantycko-zachodnioeuropejskiej i niemieckiej kultury pamięci. W rezultacie tych ożywionych dyskusji, w których uczestniczyli także politycy (przypomnijmy targi w Lipsku w 2004 roku i gest Salomona Korna, wiceprzewodniczącego Centralnej Rady Żydów w Niemczech, 
który wyszedł z sali na znak protestu po zrównującym nazizm i komunizm przemówieniu Sandry Kalniete, minister spraw zagranicznych Lotwy), do zachodniej opinii publicznej, w tym do społeczności akademickiej, zaczął coraz wyraźniej docierać odmienny charakter zarówno wojennej historii, jak i wyobrażeń o niej w Europie Wschodniej.

Odpowiedź na pytanie, na czym ta odmienność miałaby polegać, nie była jednak prosta. Początkowo doszukiwano się jej w tak zwanym „doświadczeniu Gułagu”, którym to terminem, rozciagliwym i mglistym, określano różne zbrodnie sowieckie o historii nie do końca rozpoznanej przez zachodnią opinię publiczna. W tekstach balansujących na granicy tez publicystycznych i naukowych zestawiano więc pamięć Gułagu (i szerzej komunizmu) z pamięcią Zagłady (Blaive et al. 2011; Droit 2007); starano się też jakoś ująć pamięć o ofiarach terroru stalinowskiego w szersze ramy europejskości budowanej na idei praw człowieka - w tym kontekście największy rozgłos zdobyła koncepcja koncentrycznych kręgów pamięci zbiorowej autorstwa politologa Klausa Leggewie (2011). W tomach, które ukazały się w latach okołoakcesyjnych, nazwijmy je pierwszą falą badań nad pamięcia po zjednoczeniu, ciagle jednak Europa Wschodnia stanowiła tylko margines, zaledwie przyczynek do badań prowadzonych w krajach Zachodu (np. Müller 2002, Jarausch, Lindenberger 2007; Kansteiner et al. 2006; Pakier i Stråth 2010). Niemniej dyskusja prowadziła w kierunku zasadniczo istotnym, choć stosunkowo oczywistym: po prawej stronie byłej żelaznej kurtyny nie można mówić o II wojnie światowej, nie biorąc pod uwagę pamięci o komunizmie.

W pracach, które proponuję tu określić mianem drugiej fali, Europa Wschodnia staje się pełnoprawnym i centralnym tematem badań porównawczych i transnarodowych. Warto tu zwrócić uwagę na: koncepcję regionów pamięci rozwijana przez niemieckiego historyka Stefana Troebsta (2013); próbę rozpoznania wpływu transformacji lat 1989-1990 na pamięć autobiograficzna, obejmującą siedem państw, pióra brytyjskiego historyka Jamesa Marka (2010); rozważania na temat etyki politycznego pojednania w kontekście polsko-niemieckim i polsko-ukraińskim polskiej socjolog Karoliny Wigury (2011); porównawcze prace na temat polityki historycznej autorstwa badaczy francuskich i rosyjskich (Mink, Neumayer 2013; Miller, Lipman 2012), a także studia nad regionalna pamięcią kulturową: nostalgią i sposobami pamiętania o komunizmie (Todorowa 2010; Todorowa, Gille 2010) oraz nad polsko-niemieckimi miejscami pamięci (Traba, Hahn 2012). Prace te dziela perspektywy dyscyplinarne, łączą je jednak: znakomity warsztat, długoletnia refleksja i brak skłonności do upraszczających 
tez o naturze i zawartości pamięci zbiorowej. Znamienne dla publikacji pierwszej fali koncepcje teleologiczne, wedle których Europa Wschodnia miałaby przede wszystkim nadrabiać zapóźnienia wobec Zachodu, ustępują tu miejsca historycznym opisom okoliczności powstawania wyobrażeń zbiorowych oraz pogłębionym analizom ich funkcji i zawartości.

Omawiana tu książkę napisaną przez siedmiu autorów należy zaliczyć właśnie do tej drugiej fali. Powstała w ramach projektu Memory at War: Cultural Dynamics in Poland, Russia and Ukraine, prowadzonego w latach 20102013 przez międzynarodowy zespół interpretujący współczesne przemiany pamięci kulturowej w Europie Wschodniej. Szefem projektu był badacz kultury rosyjskiej, pracujący na uniwersytecie w Cambridge, Alexander Etkind. Treścią Remembering Katyn jest historia pamięci kulturowej o zbrodni katyńskiej. Książka składa się ze wstępu i ośmiu rozdziałów, z których pięć dotyczy odpowiednio historii wyobrażeń katyńskich w Polsce, na Ukrainie, Białorusi, w krajach bałtyckich i w Rosji. Rozdział na temat Polski jest uzupełniony osobnym rozdziałem (drugim) przedstawiającym analizę i recepcję filmu Andrzeja Wajdy Katyń (2007). Rozdział siódmy opisuje historię zespołu memorialnego w Katyniu i wreszcie rozdział ostatni, a właściwie coda książki, zatytułowany Katyn-2, dotyczy wyobrażeń katyńskich rozwijanych po katastrofie samolotu prezydenckiego w Smoleńsku (2010). Do całości dołączono przejrzyste kalendarium lat 1939-2011, mape miejsc zbrodni i kilkanaście fotografii.

Książka ma trzy podstawowe zalety. Po pierwsze, w przejrzysty i przystępny, a zarazem rzetelny sposób zdaje zachodniemu czytelnikowi relację z historii zbrodni katyńskiej oraz historii wyobrażeń o niej w literaturze, filmie i polityce historycznej. Chociaż nie powtórzy niedawnego sukcesu czytelniczego słynnych Skrwawionych ziem Tymothy'ego Snydera (2011), który na nowo pokazal masowy charakter zbrodni wojennych w Europie Wschodniej, to jednak dzięki entuzjastycznym recenzjom, w tym rekomendacjom samego Snydera, a także Aleidy Assmann i Jaya Wintera najwyższej klasy badaczy pamięci kulturowej - ma ona szansę zaistnieć w sylabusach zachodnich uczelni i poszerzyć wiedzę o Europie Wschodniej XX wieku.

Po drugie, o co wcale nie łatwo, książka jest także ciekawa dla czytelnika z Europy Wschodniej, ponieważ zestawia i porównuje interpretacje zbrodni katyńskiej rozwijane w państwach sąsiadujących. Polski czytelnik będzie dobrze znał treści przedstawione w rozdziale Katyn in Poland, czyli mobilizację społeczną do walki z kłamstwem katyńskim w czasach PRL oraz stanowiące przedmiot interpretacji autorów teksty Józefa Mackiewicza, Jacka Trznadla 
i Włodzimierza Odojewskiego. Pewnie też tylko nieznacznie wzbogaca jego wiedzę intepretacja filmu Andrzeja Wajdy czy informacje ze smoleńskiej cody książki. Z pewnością jednak skorzysta z przeglądu polityki sowieckiej i rosyjskiej w rozdziałach Katyn in Russia i Katyn in Katyn, pokazujących zorganizowane zapominanie i reinterpretacje zbrodni katyńskiej na przestrzeni kilkudziesięciu lat. Rozdział na temat Białorusi zajmująco przedstawia powiazzanie politycznego milczenia o zbrodni w Katyniu z cisza o zbrodni w Kuropatach. Niewielu Polaków zna historie ukraińskich dysydentów, którzy w latach sześćdziesiątych przypłacili wyrokami łagru i więzienia żądania ujawnienia prawdy o zbrodni katyńskiej, co pokazuje świetny rodział na temat Ukrainy. Niewielu też zdaje sobie sprawę z tego, że polsko-rosyjskie spory wokół zbrodni katyńskiej czy film Katyń stanowiły swoiste punkty orientacyjne dla polityki historycznej w krajach bałtyckich.

Po trzecie, i tutaj warto zatrzymać się dłużej, książka jest ważną pozycją w ramach badań pamięcioznawczych (memory studies). Przede wszystkim proponuje udana rekonceptualizację lieu de mémoire Pierre'a Nory, czyli kluczowego pojęcia w kulturoznawczej gałęzi tych badań; pojęcia, które zrobiło międzynarodową karierę, choć początkowo miało służyć podtrzymaniu francuskiej tożsamości narodowej. Badania lieux de mémoire przeprowadzono w kilkunastu krajach, choć ich autorzy musieli poradzić sobie z niejednoznacznością tego pojęcia (Kończal 2012). Autorzy Remembering Katyn (2012: 10) w miejsce lieu de mémoire - obejmującego materialne i niematerialne elementy dziedzictwa danej wspólnoty - proponuja memory event jako kategorię zjawisk niezależnych od przestrzeni (deterritorialized), o znaczeniu chwilowym (temporal), prowadzącym jednak do istotnych przewartościowań w przestrzeni publicznej i w rytuałach upamiętniających. To pojęcie pozwala uchwycić zjawisko międzynarodowych „podróży” wyobrażeń o przeszłości. W tym zakresie pasuje do intuicji innych badaczy, którzy w ostatnich latach zaproponowali kategorie, takie jak memory travels (Erl 2011), borrowings (Miller, Lipman 2012) czy multidirectional memory (Rothberg 2010). Za pomoca tej kategorii autorzy Remembering Katyn przekonująco pokazuja, że w ostatnich latach zbrodnia katyńska stała się transnarodowym memory event dwukrotnie - za sprawa filmu Wajdy oraz po katastrofie smoleńskiej.

Drugą ważna decyzją w warstwie konceptualnej jest konsekwentnie stosowane rozróżnienie pomiędzy metonimią (powiązaniem zjawisk) a metafora (przenośnia) w odniesieniu do wyobrażeń katyńskich. Autorzy pokazują, że w Polsce i Rosji odniesienia do Katynia stosowano głównie metonimicznie, jak w słynnych wypowiedziach Donalda Tuska: „my, Polacy jesteśmy jedna, wielką rodziną katyńską”, czy Sergieja Karaganowa: „cała 
Rosja to jeden Katyń"; podczas gdy na Ukrainie, Białorusi i w państwach bałtyckich Katyń występuje przede wszystkim jako metafora dla nazywania innych zbrodni sowieckich; na przykład ukraińskim Katyniem bywa określane wymordowanie tysięcy ludzi przez NKWD w latach 1927-1939 w Winnicy. Można mieć nadzieję, że z tych dwóch powodów książka nie tylko zostanie zakwalifikowana jako użyteczna pozycja na półce z area studies dotyczących Europy Wschodniej, ale również wzbogaci aparat badań pamięcioznawczych.

Na koniec kilka uwag krytycznych - zarówno do samej książki, jak i na jej przykładzie do kierunku badań, określonego tutaj mianem drugiej fali. Zważywszy na kompetencje autorów, zaskakuje zdawkowe potraktowanie pamięci o Katyniu w przestrzeni atlantycko-zachodnioeuropejskiej. Czytelnik znajdzie co prawda wzmianki dotyczące polityki brytyjskiej wobec zbrodni katyńskiej podczas II wojny światowej, Komisji Śledczej Kongresu USA (1951-1952), pomnika katyńskiego w Sztokholmie (1975) czy działań strony polskiej w Europejskim Trybunale Praw Człowieka w Strasburgu w ostatnich latach, jednak są to tylko wtrącenia, niemające charakteru wyczerpujących omówień. Można powiedzieć, że kiedy w pierwszej fali za mało było Europy Wschodniej w Europie Zachodniej, to teraz za mało jest euroatlantyckiej kultury pamięci w związku z procesami pamięci w Europie Wschodniej. Takie upraszczające zabiegi nie służą dobrze pisaniu historii transnarodowej.

Warto też podkreślić, że niemal wszystkie wspomniane tu książki - w tym recenzowana - zajmuja się kwestiami politycznymi i/lub kulturowymi w wymiarze porównawczym: a zatem pamięcia przetworzona, skodyfikowaną i znarratywizowaną lub polityką historyczna, czyli projektami zagospodarowania pamięci jednostek. Z wyjątkiem wybitnej książki Jamesa Marka, któremu trochę szkodzi politycyzujący schematyzm w prezentowaniu autobiografii wysłuchanych przez niego narratorów, nie dotyczą one pamięci indywidualnej i zagregowanej indywidualnej, tradycyjnie badanej przez socjologów. Nie dają wobec tego wglądu w to, na ile wydarzenia medialne, polityka pamięci, poezja i literatura faktycznie kształtuja i zmieniaja jednostkowe wyobrażenia na temat przeszłości. Zatem bez równie pogłębionych i porównawczych analiz w tym zakresie - transnarodowe studia nad pamięcią zbiorową w Europie Środkowo-Wschodniej pozostana niepełne.

Wreszcie uwaga dla recenzji nietypowa, bo dotycząca przyjęcia Remembering Katyn w Polsce. Według mojej wiedzy, jak dotąd (czerwiec 2013), książka wzbudziła tylko umiarkowane zainteresowanie. W kraju, w którym 
wydarzenia smoleńskie są omawiane codziennie, w którym także do tradycji należy narzekanie na niezrozumienie sprawy katyńskiej przez Zachód, gdy „zachodni” autorzy zadali sobie trud, by sprawę wyjaśnić i objaśnić, ich wysiłki sa ignorowane. Może jest to tylko sprawa języka, w którym książka została napisana? W takim razie tym bardziej zasługuje ona na polskie wydanie.

Bibliografia:

/// Blaive M., Gerbel C., Lindenberger T. red. 2011. Clashes in European Memory: The Case of Communist Repression and the Holocaust, StudienVerlag, Innsbruck-Wien-Bozen.

/// Droit E. 2007. Le Goulag contre la Shoah. Mémoires officielles et cultures mémorielles dans l'Europe élargie, „Vingtième Siècle. Revue d'histoire” 2007, nr 94, s. 101-120.

/// Erll A. 2011. Travelling Memory, „Parallax” 2011, nr 17, 4, s. 4-18.

/// Etkind A., Finnin R., Blacker U., Fedor J., Lewis S., Mälksoo M., Mroz M. 2012. Remembering Katyn, Polity Press, Cambridge-Malden.

/// Jarausch K., Lindenberger T. red. 2007. Conficted Memories. Europeanizing Contemporary Histories, Berghahn Books, New York, Oxford.

/// Kansteiner W., Lebow R., Fogu C. red. 2006. The Politics of Memory in Postwar Europe, Duke University Press, Durham and London.

/ / Kończal K. 2012. Les Lieux de Mémoire/Realms of Memory: The Unparalleled Career of a Research Concept, „Acta Poloniae Historica” 2012, nr 106, s. 5-30. /// Leggewie C., współpraca: A. Lang. 2011. Der Kampf um die europäische Erinnerung. Ein Schlachtfeld wird besichtigt, C.H. Beck Verlag, München.

/// Mark J. 2010. The Unfinished Revolution: Making Sense of the Communist Pat in Central-Eastern Europe, Yale University Press, New Heaven and London.

/// Miller, A., Lipman M. red. 2012. The Convolutions of Historical Politics, CEU Press, Budapest-New York.

/// Mink G., Neumayer L. red. 2013. History, Memory and Politics in Central and Eastern Europe. Memory Games, Palgrave Macmillan, Basingstoke $-\mathrm{New}$ York.

/// Müller J-W. red. 2002. Memory and Power in Post-War Europe, Cambridge UP, Cambridge. 
/// Pakier M., Stråth B. red. 2010. European Memory? Contested Histories and Politics of Remembrance, Berghahn Books, New York, Oxford.

/// Rothberg M. 2009. Multidirectional Memory: Remembering the Holocaust in the Age of Decolonization, Stanford University Press, Stanford.

/// Snyder T. 2011. Skrwawione Ziemie. Europa miedsy Hitlerem a Stalinem, tłum. B. Pietrzyk, Świat Książki, Warszawa.

// / Todorova M. red. 2010. Remembering Communism: Genres of Representation, Social Science Research Council, New York.

/// Todorova M., Gille Z. red. 2010. Post-Communist Nostalgia, Berghahn Books, New York.

/// Traba R. 2011. Gdzie jesteśmy? Nowe otwarcie w polskich badaniach pamieci zbiorowej i ich europejski kontekst, „Kultura i Społeczeństwo” 2011, nr LV/4, s. 3-10.

/// Traba R., Hahn H. red., współpraca: M. Górny, K. Kończal. 2012. Polsko-niemieckie miejsca pamieci, t. 3: Paralele, Wydawnictwo Naukowe Scholar, Warszawa.

/// Troebst S. 2013. Erinnerungskultur - Kulturgeschichte - Geschichtsregion. Ostmitteleuropa in Europa, Franz Steiner Verlag, Stuttgart. 